OPEN ACCESS

Edited by:

Hang Xiao,

University of Massachusetts Amherst,

United States

Reviewed by:

Miryam Amigo-Benavent

University of Limerick, Ireland

Joana Costa,

University of Porto, Portugal

${ }^{*}$ Correspondence:

Jinghua Yu

yujinghuamail@163.com

Specialty section:

This article was submitted to

Food Chemistry,

a section of the journal

Frontiers in Nutrition

Received: 02 June 2021

Accepted: 19 August 2021

Published: 17 September 2021

Citation:

Li H, Zhao T, Li H and Yu J (2021)

Effect of Heat Treatment on the

Property, Structure, and Aggregation

of Skim Milk Proteins.

Front. Nutr. 8:714869.

doi: 10.3389/fnut.2021.714869

\section{Effect of Heat Treatment on the Property, Structure, and Aggregation of Skim Milk Proteins}

\author{
Hongbo $\mathrm{Li}^{1,2}$, Tingting $\mathrm{Zhao}^{2}$, Hongjuan $\mathrm{Li}^{2}$ and Jinghua $\mathrm{Yu}^{2 *}$ \\ ${ }^{1}$ Beijing Advanced Innovation Center for Food Nutrition and Human Health, Beijing Technology and Business University \\ (BTBU), Beijing, China, ${ }^{2}$ State Key Laboratory of Food Nutrition and Safety, Key Laboratory of Food Nutrition and Safety, \\ Ministry of Education, College of Food Engineering and Biotechnology, Tianjin University of Science and Technology, Tianjin, \\ China
}

To study the mechanism of heat-induced protein aggregates, skim milk was heated at 55 , $65,75,85$, and $95^{\circ} \mathrm{C}$ for $30 \mathrm{~s}$. Then, the sulfhydryl content, surface hydrophobicity, and secondary structure of heat-treated skim milk were studied. Treating skim milk at different temperatures induced a decrease in sulfhydryl content $\left(75.9 \%\right.$ at $\left.95^{\circ} \mathrm{C}\right)$ and an increase in surface hydrophobicity $\left(44 \%\right.$ at $\left.95^{\circ} \mathrm{C}\right)$ with a disrupted secondary structure containing random coil, $\beta$-sheet, and $\beta$-turn of skim milk proteins. The change in these properties facilitated aggregate formation through disulfide bonds and hydrophobicity interaction. Microstructural observation also showed a higher degree of aggregation when skim milk was heated at 85 and $95^{\circ} \mathrm{C}$. The result of two-dimensional polyacrylamide gel electrophoresis demonstrated that the aggregates consisted of a high proportion of $\kappa$-casein, $\beta$-lactoglobulin, and other whey proteins.

Keywords: heat treatment, skim milk, property, protein aggregation, 2D-PAGE

\section{INTRODUCTION}

Milk derived from domesticated mammalian animals has a long history of being a part of the human diet. The current milk and milk products for human consumption are mainly from cows, followed by buffaloes, goats, horses, yaks, and camels (1). In the processing of these dairy products, heat treatment is an essential step to reduce the potential risk of survival of pathogenic microorganisms and extend the shelf life of final products. It can also improve the functional properties of some specific dairy products, such as yogurt and cheese $(2,3)$. Heat treatment has a significant effect on the protein network of dairy product (4). It is well-known that heat-treated milk can form a gel network with better strength and firmness in a shorter time (5). The application of heat leads to different reactions among milk proteins, contributing to the denaturation and/or aggregation of whey proteins and formation of complexes between caseins and whey proteins (6-9).

In dairy proteins, caseins with molecular weight ranging from 19 to $25.2 \mathrm{kDa}$ account for about $80 \%$ of total proteins, while whey proteins represent $20 \%$. The main components in whey proteins are $\beta$-lactoglobulin $(\beta$-LG) and $\alpha$-lactalbumin ( $\alpha$-LA), representing 50 and $25 \%$, respectively, followed by minor constituents, such as bovine serum albumin (BSA), lactoferrin, and immune globulin (10). In these proteins, caseins are relatively stable at a high temperature, and whey proteins are more susceptible to heat treatment (11). The denaturation of $\beta$-LG and $\alpha$-LA occurs at temperatures above $70-75^{\circ} \mathrm{C}$, but the other whey proteins such as BSA and lactoferrin begin to denature 
at a lower temperature of about $65^{\circ} \mathrm{C}(12,13)$. Considerable research studies have been conducted to study the composition of complexes and reactions between proteins $(14,15)$. Results showed that non-covalent interactions between whey proteins and casein micelles, and the formation of disulfide bond are the most important reactions in the process of heat treatment (16). During the heat treatment of milk, $\beta$-LG $/ \kappa$-casein complexes are formed with the exchange of thiol-disulfide (17). It has been reported that $\beta$-LG containing a free sulfhydryl group and two disulfide bonds plays an important role in the formation of $\beta$-LG/ $\kappa$-casein complexes $(18,19)$.

At present, the effect of heat treatment on milk proteins is mainly focused on the interaction between the proteins, but there are few studies on the properties and structure of total milk proteins. According to the temperature range of whey protein denaturation, $55,65,75,85$, and $95^{\circ} \mathrm{C}$ are selected as the heat treatment temperature on skim milk. The goal of this study is to explore the mechanism of heat-induced protein aggregates after heat treatment on skim milk, and the interaction of different denatured milk proteins.

\section{MATERIALS AND METHODS}

\section{Sample Preparation}

Fresh cow milk was purchased from a local dairy plant, and $0.02 \%$ $(\mathrm{w} / \mathrm{v})$ sodium azide was added to prevent bacterial growth. Total protein was determined by the Association of Official Analytical Chemists (20) Method Nos. 991.20 with a conversion factor of 6.38. Cow milk was centrifuged at $2,000 \times g$ for $20 \mathrm{~min}$ at $4^{\circ} \mathrm{C}$ to remove the cream, then the skim milk was heated at 55,65 , 75,85 , and $95^{\circ} \mathrm{C}$ for $30 \mathrm{~s}$ in a recirculating tubular heat exchanger made in the laboratory. This heat exchanger contained a tubular coil ( $1 \mathrm{~mm}$ inner diameter) located in a thermostatic water bath and controlled with a constant-flow pump. After heat treatment, the skim milk was rapidly cooled in an ice water bath.

\section{Sulfhydryl Determination}

The sulfhydryl content of the heat-treated samples was determined using the 5,5'-dithiobis (2-nitrobenzoic acid) (DNTB) method. Three hundred microliters of the samples were mixed with $5 \mathrm{ml}$ urea $\left(8 \mathrm{~mol} \mathrm{~L}^{-1}\right)$ and $20 \mu \mathrm{l}$ DNTB $(4 \mathrm{~m}$ $\mathrm{ml}^{-1}$ ) (Borunlaite Co., Ltd., Beijing, China) and incubated for $15 \mathrm{~min}$ at room temperature. Then, the mixture was immediately measured at $412 \mathrm{~nm}$ with a UV-752 UV-vis spectrophotometer (Sunnu Hengping Co., Ltd., Shanghai, China). The mixture without DNTB as a blank control and sulfhydryl content was expressed as micromoles sulfhydryl per milliliter milk.

\section{Surface Hydrophobicity}

The surface hydrophobicity of the heat-treated samples was estimated using the 8-anilino-1-naphthalene sulphonic acid (ANS)-binding fluorimetric assay method. A solution of 8 mmol L ${ }^{-1}$ ANS (Sigma, Shanghai, China) was prepared in a $0.01 \mathrm{~mol} / \mathrm{L}$ PBS buffer ( $\mathrm{pH}$ 6.7). The heat-treated samples were also diluted using the PBS buffer to $0.0025,0.005,0.01$, and $0.02 \%(\mathrm{w} / \mathrm{v})$, respectively. For each sample, $20 \mu \mathrm{l}$ ANS was added and equilibrated for $1 \mathrm{~h}$. The fluorescence intensity was measured with a RF-5301 fluorescence spectrophotometer (Shimadu, Shanghai, China), with the excitation wavelength set at $390 \mathrm{~nm}$ and the emission wavelength at $470 \mathrm{~nm}$ (Ex 390/Em 470). The excitation and emission slits were both set at a bandwidth of $5 \mathrm{~nm}$.

\section{Fourier Transform Infrared Measurement}

The secondary structure of the heat-treated samples was analyzed using a Vector22 FTIR (Bruker, Karlsruhe, Germany) spectrometer with a distributed temperature gradient sensing (DTGS) detector. All spectra were recorded within the range of $4,000-650 \mathrm{~cm}^{-1}$ with a $4 \mathrm{~cm}^{-1}$ resolution and 32 scans. The measurements were performed in a dry atmosphere at room temperature. In order to reduce the influence of steam absorption in the measurements, dry nitrogen was constantly used.

\section{Scanning Electron Microscopy}

The microstructure of the heat-treated samples was determined using SEM SU1510 (Hitachi, Tokyo, Japan). The heat-treated samples were fixed in $2.5 \%$ glutaraldehyde for $3 \mathrm{~h}$ at $4^{\circ} \mathrm{C}$, and washed three times using a $0.1 \mathrm{~mol} \mathrm{~L}^{-1} \mathrm{PBS}$ buffer ( $\mathrm{pH}$ 7.2). After washing, the samples were dehydrated using $50,70,90$, and $100 \%$ ethanol. Then, ethanol was replaced by isoamyl acetate, and the samples were dried at room temperature. The dried samples were coated with a 4-nm gold layer and observed.

\section{PAGE Analysis}

The aggregates and interactions of proteins in the heat-treated skim milk samples were characterized with the two-dimensional sodium dodecyl sulfate-polyacrylamide gel electrophoresis (2D-PAGE) method. For the first dimension (non-reduced SDSPAGE), $20-\mu$ l samples were loaded and run on $5-15 \%$ homemade Tris- $\mathrm{HCl}$ gel. The gel strip including aggregates was cut and soaked in a $\beta$-mercaptoethanol ( $\beta$-ME) buffer for $2 \mathrm{~h}$ and then placed on top of $5-15 \%$ gel for the second dimension (reduced SDS-PAGE). Electrophoresis was carried out in a Tris-glycine electrophoresis buffer. The gel was stained with Coomassie Brilliant Blue R250 and scanned using a Gel Doc XR system (Bio-Rad Laboratories Inc., Hercules, CA, United States). An unstained protein molecular weight marker (14.3-97.2 KDa; ComWin Biotech, Beijing, China) was used in all gels to identify skim milk proteins.

\section{Statistical Analysis}

Data were analyzed with SPSS 14.0 (SPSS Inc, Chicago, IL, United States) and one-way analysis of variance with Duncan's post-test was applied. The level of significance was established at $p<0.05$. All the assays were carried out in triplicate, and data were expressed as mean values \pm standard deviation (SD).

\section{RESULT AND DISCUSSION}

\section{Sulfhydryl Determination}

The sulfhydryl content of the heat-treated skim milk samples was studied. As shown in Figure 1, there is no significant change in sulfhydryl content at the lower temperature treatment (55 and $65^{\circ} \mathrm{C}$ ) compared with the sample without heat treatment, but 


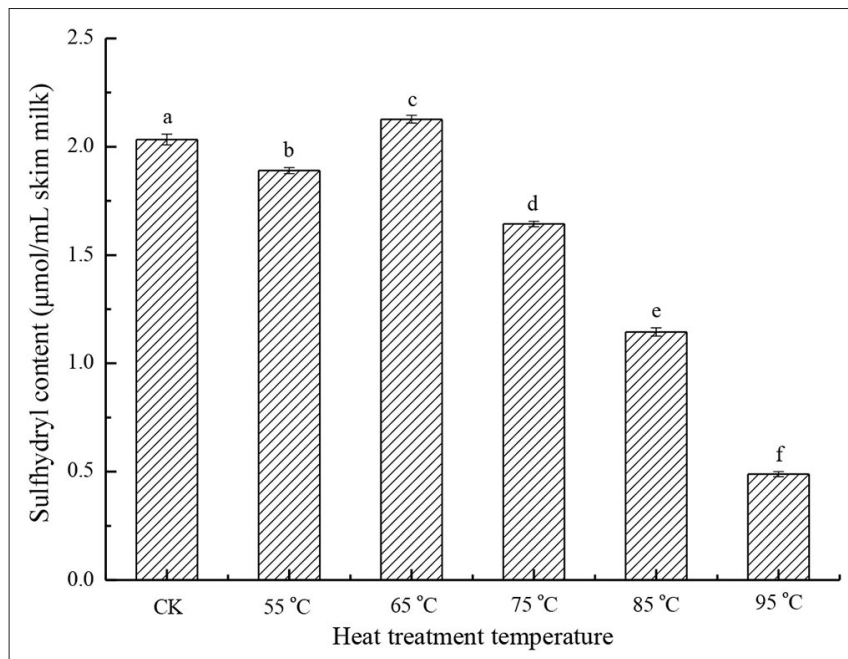

FIGURE 1 | Sulfhydryl content of different heat-treated skim milk. CK, skim milk without heat treatment.

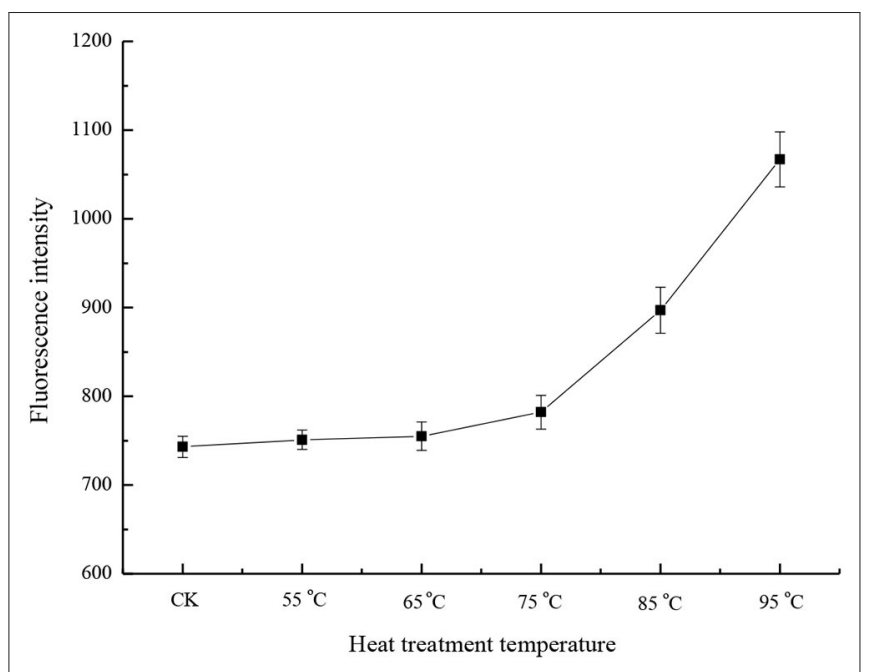

FIGURE 2 | Surface hydrophobicity of different heat-treated skim milk. CK, skim milk without heat treatment. with the increasing of heat treatment temperature, the sulfhydryl content drops significantly $(p<0.05)$. When the treatment temperature reached $95^{\circ} \mathrm{C}$, sulfhydryl content was only $24.1 \%$ of the control sample. This indicated that heat treatment induced the formation of aggregates through thiol-disulfide exchange. Sulfhydryl is one of the important functional groups in proteins, and it mainly exists in cysteine residues. In milk proteins, sulfhydryl exists in the form of a free thiol group and disulfide bond, and it is important for the maintenance of the native structure of proteins (12). Since heat treatment can cause protein aggregation through thiol-disulfide exchange, and then result in further aggregation via hydrophobic association, sulfhydryl content can be used to characterize the aggregation degree of protein samples $(17,21)$.

In milk proteins, only $\beta$-LG has a free thiol group, so the effect of heat treatment on sulfhydryl is mainly focused on $\beta$-LG (12). After heat treatment, the free thiol group of $\beta$-LG was exposed and involved in the thiol-disulfide exchange reaction, so this free thiol group has the potential to react with other proteins, such as $\kappa$-casein and BSA $(5,22)$. Cho et al. have reported that disulfide bonds and the free thiol group present in $\beta$-LG play a very important role in the formation of the $\beta$-LG $/ \kappa$-casein complex by SH/S-S interchange (18). Another possibility to reduce the sulfhydryl content is by the interaction of two $\beta$-LG molecules to form a disulfide-bonded dimer (19).

\section{Surface Hydrophobicity Analysis}

Hydrophobicity is a property that affects the functionalities of proteins, and is mainly determined by the amino acid composition of proteins. The surface hydrophobicity of the heated samples increased in the heat temperature range of 75 to $95^{\circ} \mathrm{C}$ (Figure 2). At $95^{\circ} \mathrm{C}$, the surface hydrophobicity was 1.44 times that of the control sample. This was consistent with the previous results $(23,24)$. Hiller and Lorenzen (25) studied the surface hydrophobicity of heat-treated milk proteins such as whey protein isolate, micellar casein, and BSA. The results showed that heat treatment increased the surface hydrophobicity of whey protein isolate and decreased the surface hydrophobicity of BSA, and that the treatment had a little effect on casein. Since BSA accounts for only $1.2 \%$ of milk proteins (26), the change in surface hydrophobicity mainly depends on other whey proteins. During heat treatment, $\beta$-LG is denatured first, followed by $\alpha$ LA. When milk was heated at temperatures above $65^{\circ} \mathrm{C}$, whey proteins, such as $\beta$-LG, $\alpha$-LA, BSA, and lactoferrin unfolded and exposed previously buried hydrophobic groups, so the surface hydrophobicity was increased at a higher temperature (26). Moreover, the denaturation of whey proteins is reversible at a temperature range of 55 to $65^{\circ} \mathrm{C}$, and irreversible at a higher temperature $(5,23)$.

\section{FTIR Analysis}

Fourier transform infrared spectroscopy was selected to obtain the spectrum of skim milk proteins, which illustrated protein conformation. The FTIR spectra of the samples with different heat treatments are shown in Figure 3. Generally, the FTIR spectra of proteins have a strong absorption band in the 1,700$1,600 \mathrm{~cm}^{-1}$ region (amide $\mathrm{I}$ ), which indicates the $\mathrm{C}=\mathrm{O}$ stretching mode of the peptide chain. In the amide I region, the band that appears at $1,660-1,640 \mathrm{~cm}^{-1}$ represents $\alpha$-helix and random coil, and the band that appears at $1,640-1,620 \mathrm{~cm}^{-1}$ represents $\beta$-sheet. Figure 3 shows that amide I peak positions have changed slightly in the different samples. Position altering in amide I revealed the change in the secondary structure of milk proteins. In order to obtain further information on secondary structural changes, the OMNIC analysis procedure was used to calculate the proportions of $\alpha$-helix, $\beta$-sheet, $\beta$-turn, and random coil in skim milk proteins (Table 1). Random coil was increased, and $\beta$-turn was decreased as the heat temperature increased, suggesting the direct conversion of regular $\beta$-turn into an irregular random coil with the reduction of the intramolecular 


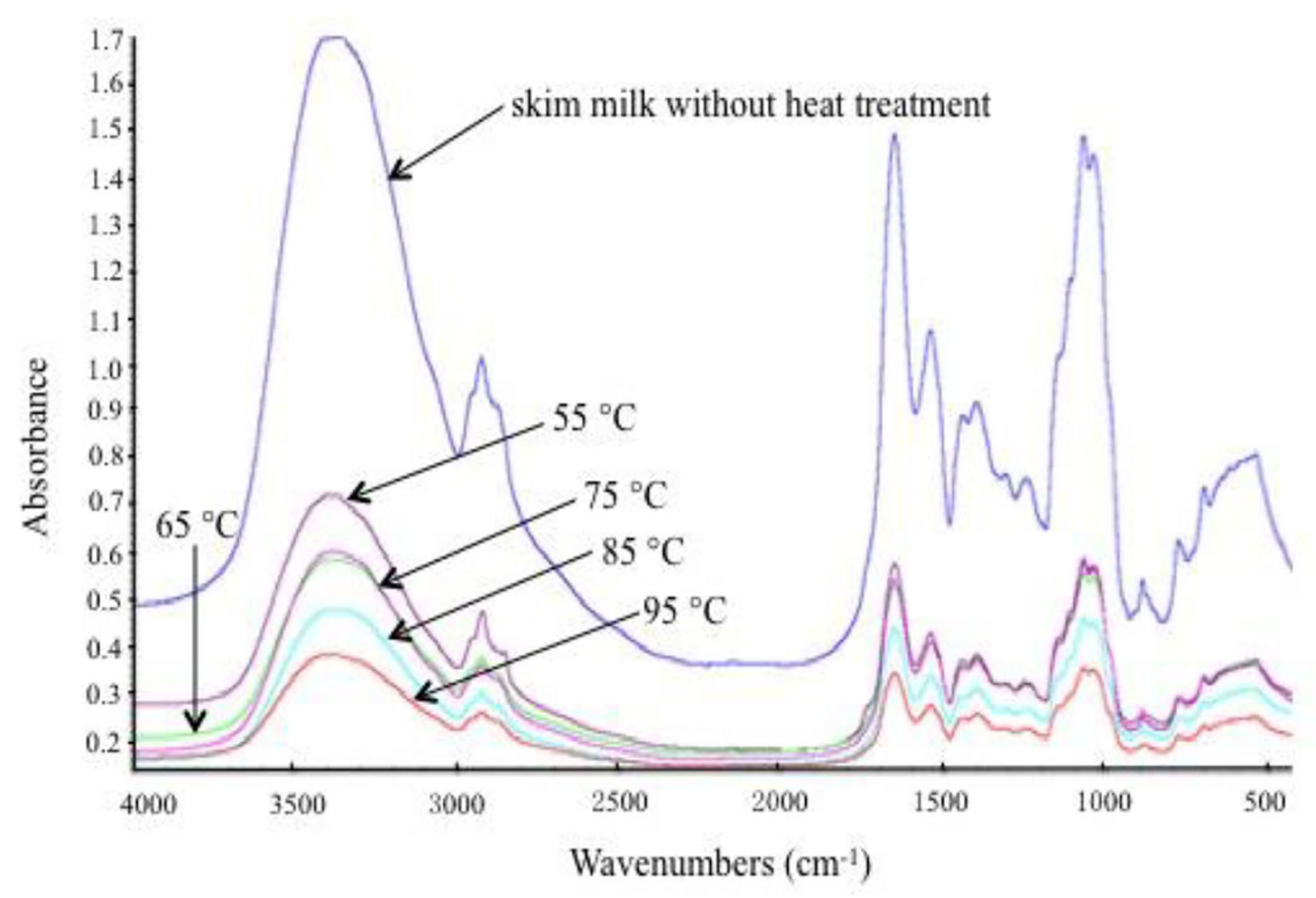

FIGURE 3 | Fourier transform infrared (FTIR) spectra of different heat-treated skim milk.

TABLE 1 | Percentage of secondary structures of skim milk heat-treated at different temperatures.

\begin{tabular}{|c|c|c|c|c|}
\hline Heat treat temperature & $\beta$-sheet & Random coil & $\alpha$-helix & $\beta$-turn \\
\hline Skim milk & 30.8 & 9.4 & 10.3 & 49.5 \\
\hline $55^{\circ} \mathrm{C}$ & 31.9 & 9.5 & 10.1 & 48.5 \\
\hline $75^{\circ} \mathrm{C}$ & 32.2 & 10.7 & 10.0 & 47.1 \\
\hline $85^{\circ} \mathrm{C}$ & 30.4 & 12.3 & 10.3 & 46.9 \\
\hline
\end{tabular}

hydrogen bond. The reduction of $\alpha$-helix at $95^{\circ} \mathrm{C}$ might correspond to the partial unfolding of the $\alpha$-helix region. The increase in $\beta$-sheet might be due to the exposure of hydrophobic regions of milk proteins, which is consistent with the surface hydrophobicity results. Although heat treatment affected the secondary structure of skim milk proteins, this change was not obvious. This might be because caseins, as the main protein in skim milk, mainly existed in casein micelles, and this structure was relatively stable at the above heat treatment temperature (9). Moreover, the subtle change in secondary structure related to the whey proteins. Studies have shown that the content of $\beta$ sheet in $\beta$-LG is increased when heated above $60^{\circ} \mathrm{C}$ (12), and that the formation of $\beta$-sheet in BSA is irreversible on heating above $70^{\circ} \mathrm{C}(27)$. The heat treatment of whey proteins caused an abrupt loss in some secondary structures such as disrupted random coil, $\beta$-sheet, and $\beta$-turn, resulting in the exposure of the free thiol group and, thus, increasing the exposure of inner hydrophobic amino acids (28). This further accelerated the aggregation between milk proteins through disulfide bond and hydrophobic interaction.

\section{Microstructure of Heat-Treated Skim Milk}

Scanning electron microscopy micrographs were obtained from the skim milk samples treated with different temperatures (Figure 4). The SEM images indicated that the morphology of the skim milk proteins heated at $55^{\circ} \mathrm{C}$ had little change compared with that of the control sample (Figures 4A,B). Caseins (big particles) and whey proteins (small particles) separately dispersed, and no aggregation was formed. The image of samples heated at 65 and $75^{\circ} \mathrm{C}$ (Figures 4C,D) showed that some proteins aggregated to form casein micellar particles with relatively small whey protein complexes present. The heat treatment of skim milk at $85^{\circ} \mathrm{C}$ (Figure 4E) showed a higher degree of aggregation between caseins, but also 

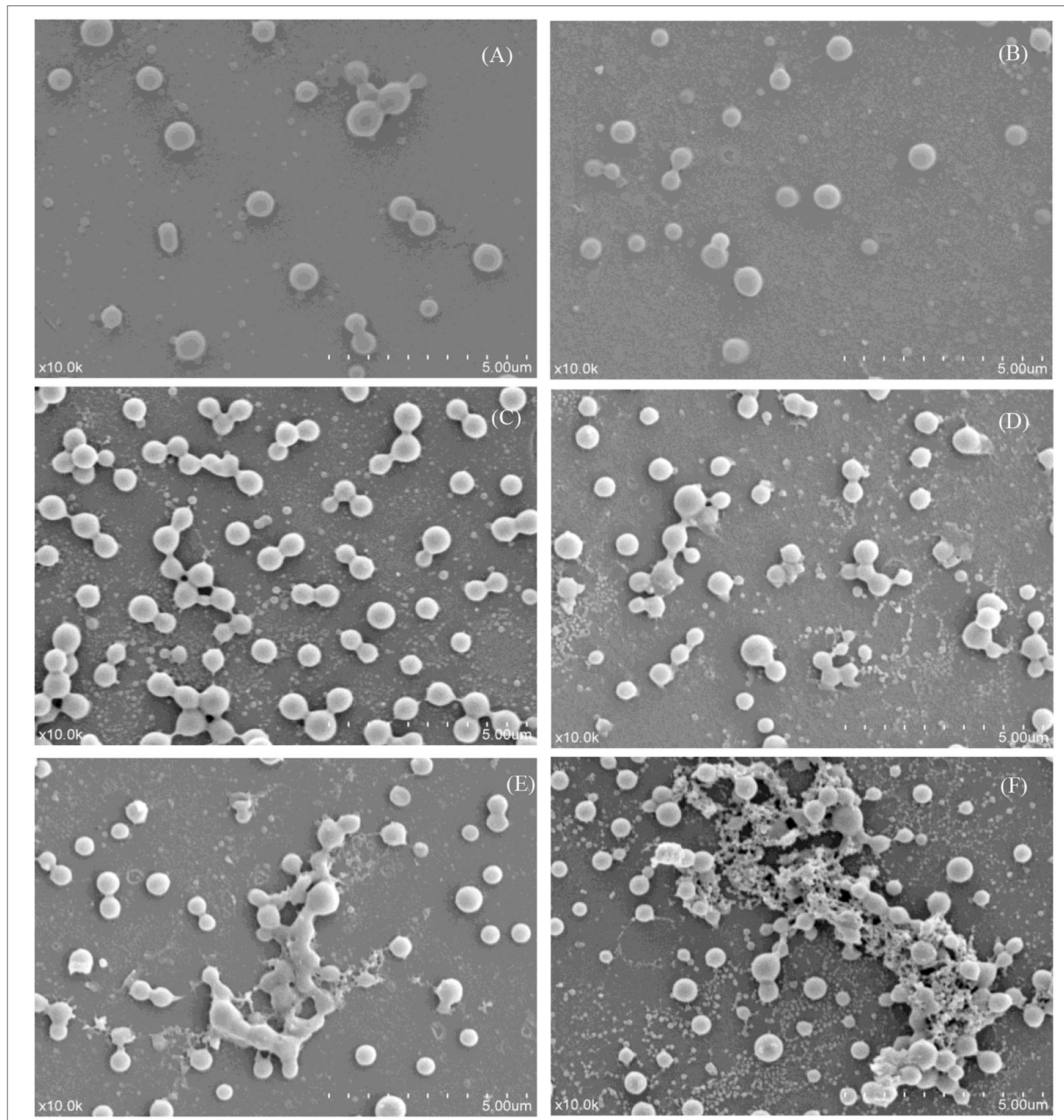

FIGURE 4 | Scanning electron micrographs of different heat-treated skim milk. (A) Skim milk without heat treatment; (B-F) skim milk heat treated at 55, 65, 75, 85, and $95^{\circ} \mathrm{C}$, respectively. All the micrographs were originally taken at a magnification of $10,000 \times$. The scale bar represents $5 \mu \mathrm{m}$.

demonstrated the presence of smaller whey protein complexes. The heat temperature of the sample reached $95^{\circ} \mathrm{C}$ and resulted in a rather loose and reticular structure, with the interaction between casein and whey protein. It was obvious that the aggregation was a large casein cluster aggregated by small whey protein particles (Figure $\mathbf{4 F}$ ). This aggregation had been demonstrated by disulfide bonds (29) and, to a much lesser extent, by non-covalent bonds (4). Unfortunately, it could not determine which casein and whey protein participated in the aggregation through SEM, so a 2D-PAGE analysis was performed to study the interaction between milk proteins. 
A

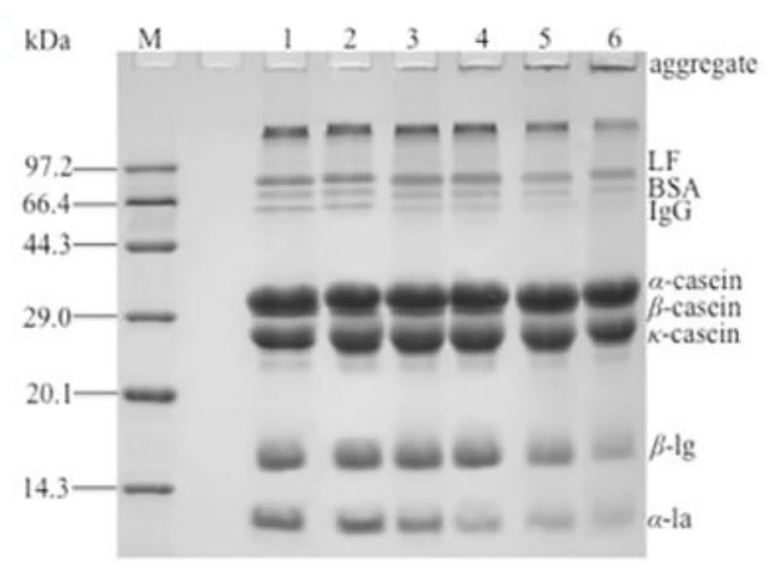

B

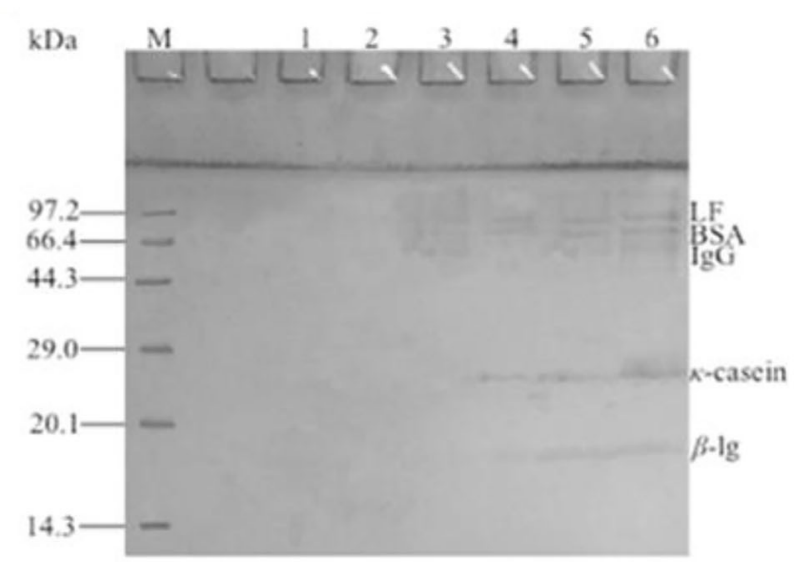

FIGURE 5 | Two-dimensional (2D) sodium dodecyl sulfate-polyacrylamide gel electrophoresis (SDS-PAGE) of different heat-treated skim milk. (A) Non-reduced SDS-PAGE of heat-treated samples; (B) reduced SDS-PAGE of protein aggregates excised from non-reduced gel. Lane M, protein marker; lane 1, skim milk without heat treatment; lanes 2-6, skim milk heat treatment at 55, 65, 75, 85, and $95^{\circ} \mathrm{C}$, respectively.

\section{PAGE Analysis}

The heat-treated samples were analyzed by non-reduced SDSPAGE (Figure 5A) and, after reduction with $\beta$-ME, by reduced SDS-PAGE (Figure 5B). As seen in Figure 5A, the intensity of bands corresponding to $\beta$-LG and $\alpha$-LA are markedly reduced with the increase in heat temperature. It can be noted that the lower heat treatment temperatures $\left(55\right.$ and $\left.65^{\circ} \mathrm{C}\right)$ limited the denaturation and aggregation of $\beta$-LG and $\alpha$-LA, with more than $95 \%$ of the above proteins remaining in its native form, similar to the sample without heat treatment, while heat treatment at $95^{\circ} \mathrm{C}$ promoted the denaturation of most $\beta$-LG and $\alpha$-LA with the rearrangement of the spatial structure. Other minor whey proteins such as BSA, lactoferrin, and immune globulin were very unstable, and the lower intensities of bands that correspond to these three proteins were observed in the samples heat-treated at $65^{\circ} \mathrm{C}$. The immune globulin G and BSA bands were essentially absent in the severely heat-treated sample $\left(95^{\circ} \mathrm{C}\right)$. Furthermore, large protein aggregates were present in the loading well-indicating molecular weights well-above $200 \mathrm{kDa}$. The density of the aggregates was enhanced with the increase in heat temperature. By comparison, the SDS-PAGE of reduced samples appeared to be similar (data not shown), indicating that no irreducible covalent bonds formed and that no polypeptide bond was cleaved by the heat treatment $(19,30)$.

The protein aggregates were excised from the non-reduced gel for the second dimension (Figure 5B). The result showed that a series of bands were present in the SDS-PAGE gel and that the molecular weight was identical to the immune globulin $\mathrm{G}$, BSA, lactoferrin, $\kappa$-casein, and $\beta$-LG, indicating that the aggregates were formed by the polymerization of the referred proteins. Because immune globulin G, BSA, and lactoferrin were denatured at a lower temperature (13), the aggregates formed at $65^{\circ} \mathrm{C}$ were mainly these three proteins. With the increase in heat treatment temperature, $\kappa$-casein and $\beta$-LG participated in the polymerization. A polymerization experiment of $\alpha$-LA, $\beta$ LG, $\kappa$-casein, and BSA by dissolving two of them in simulated milk ultrafiltrate was done (data not shown). The result showed that $\beta$-LG could react with other $\beta$-LG or $\kappa$-casein and accelerate the denaturation and aggregation of $\alpha$-LA. BSA responded to the heat treatment similarly to $\beta$-LG, except that BSA reacted at a lower temperature. This result further demonstrated that the heat-induced aggregates mainly composed by $\beta$-LG, $\kappa$-casein and BSA. This was similar with the previous reports $(5,19,31)$. It was generally considered that $\beta$-LG could react with other $\beta$-LG or $\kappa$-casein through disulfide bonds $(17,18)$. The result of sulfhydryl content showed that the free thiol group was used to form disulfide bond with other milk protein, so the sulfhydryl content dropped significantly with the increase in heat treatment temperature. In general, reactivity of free thiol group is dependent on the protein unfolding degree, as well as disulfide interchange occurring at high temperature (29). In the SDS-PAGE, monomer structure of $\kappa$-casein and $\beta$-LG were observed after aggregates were reduced by $\beta$-ME. This indicated that the new disulfide bond existed in the aggregates, and this result was consistent with the decrease in sulfhydryl content. However, $\alpha$-LA was not observed in the SDS-PAGE, and this might be because of the intensity of aggregates containing $\alpha$-LA was too low to observe. Although $\alpha_{\mathrm{s} 2}$-casein, which had two Cys residues, did not react with $\beta$-LG, it was present as a dimer with intermolecular disulfide bonds (32). This was because $\alpha_{\mathrm{s} 2}$-casein was not located at the surface of the micelle, and the disulfide bonds were not accessible to the denaturing or denatured $\beta$ LG (30). The aggregates of the other two caseins, $\alpha_{s 1}$-casein and $\beta$-casein (12), were formed by hydrophobic interaction, so $\alpha_{\mathrm{s} 1}$-casein and $\beta$-casein were absent from the SDS-PAGE gel.

\section{CONCLUSION}

In this study, the mechanism of heat-induced milk protein aggregates was investigated in detail. The result showed that heat treatment decreased sulfhydryl content, increased surface 
hydrophobicity, and disrupted the secondary structure of milk proteins. The change in these properties accelerated the denaturation of milk proteins and the formation of aggregates linked by disulfide bonds and hydrophobicity interaction. Moreover, the aggregates were formed at high heat temperature mainly composed of $\kappa$-casein, $\beta$-LG, and other whey proteins.

\section{DATA AVAILABILITY STATEMENT}

The original contributions presented in the study are included in the article/Supplementary Material, further inquiries can be directed to the corresponding author.

\section{AUTHOR CONTRIBUTIONS}

This study was conceived, designed, and written by HongbL. $\mathrm{TZ}$ performed the experiments and analyzed the data. HongjL

\section{REFERENCES}

1. Goff HD. Introduction to dairy science and technology: milk history, consumption, production, and composition. In: The Dairy Science and Technology eBook. Guelph, ON: University of Guelph. Available online at: https://www.uoguelph.ca/foodscience/book-page/dairy-science-andtechnology-ebook

2. Wang W, Zhang L, Li Y, Feng Z. Heat-induced protein aggregates and difference in the textural properties of whole milk gel. J Food Qual. (2012) 35:247-54. doi: 10.1111/j.1745-4557.2012.00444.x

3. Osman M, Abdalla M, Mohammed H, Salih A. Effect of heat treatment of milk on the physicochemical, microbiological and sensory characteristics of white cheese (Gibna bayda). GSC Adv Res Rev. (2020) 3:20-8. doi: 10.30574/gscarr.2020.3.3.0044

4. Zhao X, Cheng M, Zhang X, Li X, Wang C. The effect of heat treatment on the microstructure and functional properties of whey protein from goat milk. J Dairy Sci. (2019) 103:1289-302. doi: 10.3168/jds.2019-17221

5. Wagner J, Biliaderis CG, Moschakis T. Whey proteins: musings on denaturation, aggregate formation and gelation. Cri Rev Food Sci Nutri. (2020) 60:3793-806. doi: 10.1080/10408398.2019.1708263

6. Guyomarc'h F, Nono M, Nicolai T, Durand D. Heat-induced aggregation of whey proteins in the presence of $\mathrm{k}$-casein or sodium caseinate. Food Hydrocoll. (2009) 23:1103-10. doi: 10.1016/j.foodhyd.2008.07.001

7. Wijayanti HB, Bansal N, Deeth HC. Stability of whey proteins during thermal processing: a review. Compre Rev Food Sci Food Safety. (2014) 13:1235-51. doi: 10.1111/1541-4337.12105

8. Akkerman M, Rauh VM, Christensen M, Johansen LB, Hammershoj M, Larsen LB. Effect of heating strategies on whey protein denaturation-revisited by liquid chromatography quadrupole time-of-flight mass spectrometry. J Dairy Sci. (2016) 99:152-66. doi: 10.3168/jds.2015-9924

9. Halabi A, Deglaire A, Hamon P, Bouhallab S, Dupont D, Croguennec T. Kinetics of heat-induced denaturation of proteins in model infant milk formulas as a function of whey protein composition. Food Chem. (2019) 302:125296. doi: 10.1016/j.foodchem.2019.125296

10. Villa C, Costa J, Oliveira M, Mafra I. Bovine milk allergens: a comprehensive review. Compr Rev Food Sci Food Saf. (2018) 17:137-64. doi: 10.1111/1541-4337.12318

11. Donato L, Guyomarc'h F, Amiot S, Dalgleish DG. Formation of whey protein/ $\kappa$-casein complexes in heated milk: preferential reaction of whey protein with $\mathrm{K}$-casein in the casein micelles. Int Dairy J. (2007) 17:1161-7. doi: 10.1016/j.idairyj.2007.03.011

12. Considine T, Patel HA, Anema SG, Singh H, Creamer LK. Interactions of milk proteins during heat and high hydrostatic pressure treatments - a review. Innov Food Sci Emerge Technol. (2007) 8:1-23. doi: 10.1016/j.ifset.2006.08.003 improved the manuscript. JY provided experimental technical support. All authors contributed to the article and approved the submitted version.

\section{FUNDING}

This study was financially supported by the National Key Research and Development Program of China (Grant No. 2017YFE0131800), and Tianjin Municipal Education Commission (Grant No. 2018KJ092).

\section{SUPPLEMENTARY MATERIAL}

The Supplementary Material for this article can be found online at: https://www.frontiersin.org/articles/10.3389/fnut.2021. 714869/full\#supplementary-material
13. Xiong L, Boeren S, Vervoort J, Hettinga K. Effect of milk serum proteins on aggregation, bacteriostatic activity and digestion of lactoferrin after heat treatment. Food Chem. (2021) 337:127973-83. doi: 10.1016/j.foodchem.2020.127973

14. Peram MR, Loveday $\mathrm{SM}$, Ye A, Singh $\mathrm{H}$. In vitro gastric digestion of heat-induced aggregates of $\beta$-lactoglobulin. J. Dairy Sci. (2013) 96:63-74. doi: 10.3168/jds.2012-5896

15. Li Q, Zhao Z. Interaction between lactoferrin and whey proteins and its influence on the heat-induced gelation of whey proteins. Food Chem. (2018) 252:92-8. doi: 10.1016/j.foodchem.2018.01.114

16. Chevalier F, Kelly AL. Proteomic quantification of disulfidelinked polymers in raw and heated bovine milk. $J$ Agr Food Chem. (2010) 58:7437-44. doi: 10.1021/jf101 0879

17. Xiong L, Li C, Boeren S, Vervoort J, Hettinga K. Effect of heat treatment on bacteriostatic activity and protein profile of bovine whey proteins. Food Res Int. (2019) 127:108688. doi: 10.1016/j.foodres.2019.108688

18. Cho Y, Singh H, Creamer LK. Heat-induced interactions of $\beta$ lactoglobulin A and $\kappa$-casein B in a model system. J Dairy Res. (2003) 70:61-71. doi: 10.1017/S0022029902005642

19. Xu W, He S, Ying M, Zhang Y, Wang R. Effect of the heat-induced whey proteins/ $\kappa$-casein complex on the acid gelation of yak milk. Res Adv. (2015) 5:8952-6. doi: 10.1039/C4RA14432E

20. AOAC. Official Methods of Analysis of AOAC International. 18th ed. Arlington: AOAC (2016).

21. Havea P, Carr AJ, Creamer LK. The roles of disulphide and noncovalent bonding in the functional properties of heat-induced whey protein gels. J Dairy Res. (2004) 71:330-9. doi: 10.1017/S00220299040 0024X

22. Creamer LK, Bienvenie A, Nilsson H, Paulsson M, Wanroij MV, Lowe EK, et al. Heat-induced redistribution of disulfide bonds in milk proteins. 1. bovine $\beta$-Lactoglobulin. J Agr Food Chem. (2004) 52:7660-8. doi: 10.1021/jf049 $388 \mathrm{y}$

23. Moro A, Gatti C, Delorenzi N. Hydrophobicity of whey protein concentrates measured by fluorescence quenching and its relation with surface functional properties. J Agric Food Chem. (2001) 49:4784-9. doi: 10.1021/jf00 $1132 \mathrm{e}$

24. Kim DA, Cornec M, Narsimhan G. Effect of thermal treatment on interfacial properties of $\beta$-lactoglobulin. Colloid J Interface Sci. (2005) 285:1009. doi: $10.1016 /$ j.jcis.2004.10.044

25. Hiller B, Lorenzen PC. Surface hydrophobicity of physicochemically and enzymatically treated milk proteins in relation to techno-functional properties. J Agric Food Chem. (2008) 56:461-8. doi: 10.1021/jf072 $400 \mathrm{c}$ 
26. Raikos V. Effect of heat treatment on milk protein functionality at emulsion interfaces. A review. Food Hydrocoll. (2010) 24:259-65. doi: 10.1016/j.foodhyd.2009.10.014

27. Murayama K, Tomida M. Heat-induced secondary structure and conformation change of bovine serum albumin investigated by fourier transform infrared spectroscopy. Biochemistry. (2004) 43:11526-32. doi: 10.1021/bi0489154

28. Croguennec T, O'Kennedy BT, Mehra R. Heat-induced denaturation/aggregation of $\beta$-lactoglobulin $A$ and $B$ : kinetics of the first intermediates formed. Int Dairy J. (2004) 14:399-409. doi: 10.1016/j.idairyj.2003.09.005

29. Pereira,1 RN, Costa J, Rodrigues RM, Villa C, Machado L, Mafra I, et al. Effects of ohmic heating on the immunoreactivity of $\beta$-lactoglobulin - a relationship towards structural aspects. Food Funct. (2020) 5:400213. doi: 10.1039/C9FO02834J

30. Patel HA, Singh H, Anema SG, Creamer LK. Effects of heat and high hydrostatic pressure treatments on disulfide bonding interchanges among the proteins in skim milk. J Agric Food Chem. (2006) 54:3409-20. doi: 10.1021/jf052834c

31. Hong YH, Creamer LK. Changed protein structures of bovine $\beta$-lactoglobulin $\mathrm{B}$ and $\alpha$-lactalbumin as a consequence of heat treatment. Int. Dairy J. (2002) 12:345-59. doi: 10.1016/S0958-6946(02)00030-4
32. Rasmussen LK, Højrup P, Petersen TE. Localization of two interchain disulfide bridges in dimers of bovine as2-casein. Eur J Biochem. (1992) 203:381-6. doi: 10.1111/j.1432-1033.1992.tb16561.x

Conflict of Interest: The authors declare that the research was conducted in the absence of any commercial or financial relationships that could be construed as a potential conflict of interest.

Publisher's Note: All claims expressed in this article are solely those of the authors and do not necessarily represent those of their affiliated organizations, or those of the publisher, the editors and the reviewers. Any product that may be evaluated in this article, or claim that may be made by its manufacturer, is not guaranteed or endorsed by the publisher.

Copyright (c) $2021 \mathrm{Li}$, Zhao, Li and Yu. This is an open-access article distributed under the terms of the Creative Commons Attribution License (CC BY). The use, distribution or reproduction in other forums is permitted, provided the original author(s) and the copyright owner(s) are credited and that the original publication in this journal is cited, in accordance with accepted academic practice. No use, distribution or reproduction is permitted which does not comply with these terms. 